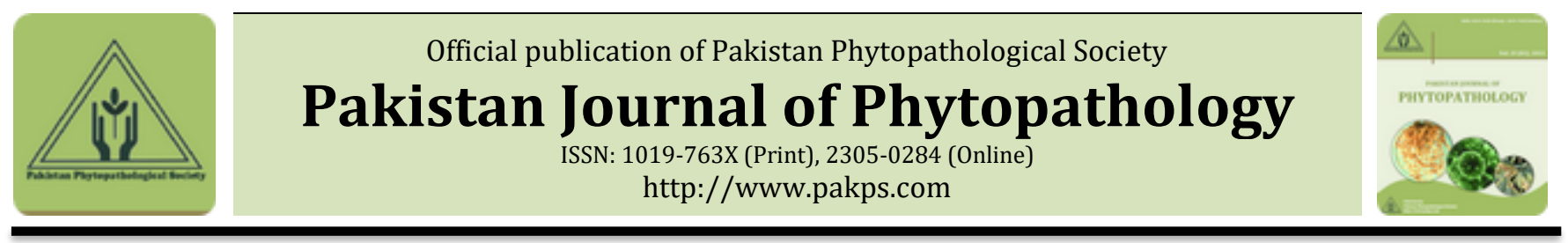

\title{
EVALUATION OF SOILBORNE PLANT PATHOGENIC FUNGAL COUNT IN VARIOUS LAND USE TYPES OF DISTRICT OKARA
}

\author{
aSumaira Naz, bSalik N. Khan, aMuhammad N. Chaudhry \\ a College of Earth and Environmental Sciences, University of the Punjab, Lahore, Pakistan. \\ ${ }^{b}$ Institute of Agricultural Sciences, University of the Punjab, Lahore, Pakistan.
}

\section{A B S T R A C T}

\begin{abstract}
A field survey was conducted in district Okara to determine existing plant pathogenic fungal count in various land use types. The target sites were classified as orchard, barren land, fallow land, cultivated land and forest land use types. Field soil samples were collected from these land use types at different depths of 15, 30 and $45 \mathrm{~cm}$ respectively. Dilution of soil samples was made in sterilized distilled water and $1 \mathrm{ml}$ was poured on to the malt extract agar (MEA) medium in $90 \mathrm{~mm}$ diameter Petri plates incubated at $25 \pm 2^{\circ} \mathrm{C}$ for 5-7 days. Purified fungal colonies of Mucor spp., Fusarium solani, Aspergillus niger, Penicillium spp., Alternaria alternata, Curvularia spp., Rhizopus spp., and Helminthosporium spp. on potato dextrose agar (PDA) medium were identified based on their morphological descriptions. These fungal counts were recovered from the soil at $30 \mathrm{~cm}$ depth which indicates an alarming situation for deep-rooted crops to soilborne fungal pathogens infestation in future.
\end{abstract}

Keywords: Soilborne fungus, fungal counts, land use types, soil microbes.

\section{INTRODUCTION}

Okara District is playing a significant role in crop productivity as it is renowned in producing sugarcane, wheat, rice and maize crops and dairy products. Oranges and Mangoes orchards are famous. It is known as Pakistan's largest city for production of these commodities (GOP, 2016). Most of the cultivated soils of this district have undergone major changes due to the cultivation of exhaustive crops resulting in land deterioration. Non-judicious input application to increase crop productivity is also a major problem. There is an increasing concern that herbicides not only affect the target organisms (weeds) but also the microbial communities present in soils, and these nontarget effects may reduce the performance of important soil functions (Hütsch, 2001). Improved soil quality often indicated by increased infiltration, aeration,

Submitted: Feb 02, 2018

Revised: Jun 13, 2018

Accepted for Publication: June 20, 2018

* Corresponding Author:

Email: raonaz85@gmail.com

(C) 2017 Pak. J. Phytopathol. All rights reserved. macropores, aggregate size, aggregate stability and soil organic matter, decreased bulk density, soil resistance, erosion and nutrient runoff and presence of soil microorganisms (Parr et al., 1992). One of its important aspects is the microbial status of the soil especially the dominance of pathogenic microbes including fungi, bacteria and viruses. Soil microorganisms play pivotal role in various biogeochemical cycles and are considered to be important for soil quality and crop productivity (Wall and Virgina, 1999). The soil, like air and water, is an integral component of our environment and together with water constitutes the most important natural resource. The wise use of this vital resource is essential for sustainable development and feeding the growing world population. Information about soil microbes helps in determining soil health and its compatibility with plant ecosystem and availability of nutrients to plants (Azam et al., 2003; DeLorenzo et al., 2001). The development of effective methods for studying the diversity, distribution, and behavior of microorganisms in soil habitats is essential for a broader understanding of soil health (Nandhini and Josephine, 2013). Soil microorganisms also influence aboveground ecosystems 
by contributing to plant health and nutrition, soil fertility and its structure (Filion Cassel and Wollum, 1999; O'donnell et al., 2001).

In the past decades, several studies have dealt with the selection of suitable criteria for assessment of soil microbes (Haney et al., 2001). Literature reports several studies on soil bacterial communities, very little research has been undertaken for soil fungus (Duarte $e t$ al., 1998).

Considering the vital role of district Okara in agriculture economy of the province a baseline was designed to report soilborne plant pathogenic fungal count in different land use types. The studies were conducted at Institute of Agricultural Sciences (IAGS) and College of Earth and Environmental Sciences, University of the Punjab, Lahore.

\section{MATERIAL AND METHODS}

Sample collection: Okara district features a humid subtropical climate with hot in summer and cold in winter. The climate of the region has considerable temperature May and June is the hottest months with the maximum temperature reaching $44^{\circ} \mathrm{C}$. January is the coldest month with minimum temperature falling to 2C. The average annual rainfall is $200 \mathrm{~mm}$ (GOP, 2016). A two years survey was conducted during November December 2014 and 2015 in three tehsils; Okara, Pakpattan and Sahiwal. Soil samples were collected with the help of hard steel type of auger of $91 \mathrm{~cm}$. The length and diameter of borer was 13 and $4 \mathrm{~cm}$ respectively. Samples were taken out of 15,30 and $45 \mathrm{~cm}$ soil depths that is sowing, ploughing and at root depth respectively from barren land, cultivated land, forest, orchard and fallow land. A total of seventy-five samples were taken from five different land use types, fifteen samples per site and five samples at different depths of 15, 30 and 45 $\mathrm{cm}$ respectively. Collected samples were kept in dry condition and packed in $18 \times 24 \mathrm{~cm}$ cellulose bags labelled with information including sampling date, place and source of collection and were designated with the special code of identification.

Samples were uniformly mixed air dried, homogenized and passed through $2 \mathrm{~mm}$ mesh sieve followed by transferring to wide-mouthed screw-topped numbered plastic bottles/jars. The bulk sample was divided into subsamples or working samples weighing 300-500g.

Isolation of Fungal Colonies: Five grams of sieved soil was added to $500 \mathrm{ml}$ sterilized distilled water in a commercial blender mixed at medium revolutions. The solution was blended three times for $30 \mathrm{sec}$ with a $3 \mathrm{~min}$ interval between the two blendings. The blended mixture was passed through a $45 \mu \mathrm{m}$ sieve in gently running tap water. Finally, $10 \mathrm{ml}$ of the mixture was added in $15 \mathrm{ml}$ cultural tubes containing MEA medium. 1 $\mathrm{ml}$ of soil suspension was aseptically poured in Petri plates containing PDA media. The plates were gently rotated so as to spread the suspension on medium. These plates were incubated at $25 \pm 2{ }^{\circ} \mathrm{C}$ for 5-7 days (Nandhini and Josephine, 2013).

Identification of Fungal Colonies: Pure cultures were obtained by transferring a media plugs ( $4 \mathrm{~mm}$ diameter) from the margins of actively growing fungal colonies to a new Petri plate containing PDA media. The fungal colonies were identified based on their microscopic studies and morphological descriptions with the help of the key developed by Barnett and Hunter (2003).

\section{RESULTS AND DISCUSSION}

Mucor spp., Fusarium solani, Aspergillus niger, Penicillium spp., Alternaria alternata, Curvularia spp., Rhizopus spp., and Helminthosporium spp. were recovered from soil samples collected from different land use types. A colony of Mucor spp. was typically white to grey. Fine threads crowned with ball-shaped clusters of spores. Sporangiophores formed globular sporangia that were supported and elevated by a column-shaped columella. Morphological descriptions of the Mucor spp. were in line with those described by Konig and Jurgen (2009) and Saito et al. (2016).

Fungal colonies of black coloration and consisted of mats of hyphae that made up a mycelium with septate and hyaline hyphae, conidiophores originated from the basal foot cell located on the supporting hyphae and terminated in a vesicle at the apex confirmed the descriptions of Aspergillus niger as described by Altieri et al. (2007) and Pawar et al. (2008).

Fungal colonies identified as Alternaria alternata was were brownish grey to black in colouration with white edges. Spores were large, brown, multicelled, obclavate and beaked as described by Picco and Rodolfi (2004) and Akhtar et al. (2004).

Cells of the Penicillium spp. were multicellular and ellipsoid. Spores were present in the form of conidia and phialidies. The conidiospores were branched while conidia were round and unicellular. Fungal colonies were initially white on PDA medium that later turned blue-green to grey-green. Similar descriptions of the Penicillium spp. were also reported by Torelli et al. 
(2006) and Ghuffar et al. (2017).

Colonies of the Rhizopus spp. were white to greyish in colouration. Coenocytic cells in hyphae with septa were only present where gametes formed. Many haploid sporangiospores were held within the sporangia structure, first as a cottony white structure and then turned black on the surface. These descriptions for the identification of Rhizopus spp. were in line with those reported by Corison et al. (1979) and Kim and Baek (2011).

Fungal colonies of colony texture with velvety to woolly appearance and olive green to black from the front and black in colour from the reverse confirmed as Helminthosporium spp. Fungal hyphae were septate, conidiophores were brown to dark brown, erect while conidia were club-shaped, pale to dark brown in colour as described by Larone (1995) and Alcorn (1988).

Curvularia spp. produced woolly colonies. The colour of the colony was white to pinkish grey initially that later turned olive brown to black. Septate, brown conidiophores, brown hyphae, and conidia were visualized. Conidiophores were simple or branched, bent from where the conidia originated. These descriptions were in line with the findings of Coombe et al. (1968) and Ashwathi et al. (2017).

Table 1 shows the presence of fungi at different depths of land use types. Helminthosporium spp. was found at the depth of $15 \mathrm{~cm}$ only mostly in forest, orchard and vegetable fields. It is basically a surface contaminant. Rhizopus spp. was only found at $15 \mathrm{~cm}$ depth in vegetable fields and in the forest while absent at other depths in these lands and other land use types. Curvularia spp. was also found at $15 \mathrm{~cm}$ and $30 \mathrm{~cm}$ in the vegetable fields, however not found in other types of the lands. A. alternata was predominant only in vegetable fields at $15 \mathrm{~cm}$ depth. Penicillium spp. and A. niger was present at both depths $15 \mathrm{~cm}$ as well as at $30 \mathrm{~cm}$ in forest and vegetable fields.

Table 1. Isolated Fungi from different Land use types at different depths.

\begin{tabular}{|c|c|c|c|c|c|c|c|c|c|}
\hline \multirow[b]{2}{*}{ Land types } & \multirow[b]{2}{*}{$\begin{array}{c}\text { Depth } \\
\text { cm }\end{array}$} & \multicolumn{8}{|c|}{ Fungi isolated from soil (no. of spores per gram of soil) } \\
\hline & & 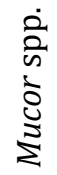 & 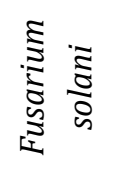 & 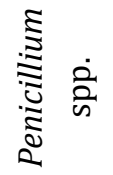 & 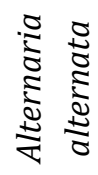 & 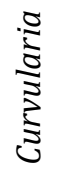 & 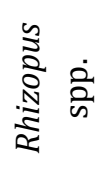 & 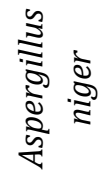 & 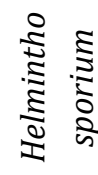 \\
\hline \multirow[t]{3}{*}{ Forest } & 15 & 9 & 5 & 6 & 0 & 0 & 5 & 7 & 4 \\
\hline & 30 & 5 & 2 & 3 & 0 & 0 & 0 & 5 & 0 \\
\hline & 45 & 2 & 0 & 0 & 0 & 0 & 0 & 0 & 0 \\
\hline \multirow[t]{3}{*}{ Orchard } & 15 & 7 & 0 & 0 & 0 & 0 & 0 & 0 & 3 \\
\hline & 30 & 5 & 0 & 0 & 0 & 0 & 0 & 0 & 0 \\
\hline & 45 & 3 & 0 & 0 & 0 & 0 & 0 & 0 & 0 \\
\hline \multirow[t]{3}{*}{ Vegetable fields } & 15 & 0 & 8 & 5 & 3 & 4 & 3 & 5 & 3 \\
\hline & 30 & 4 & 8 & 2 & 0 & 5 & 0 & 4 & 0 \\
\hline & 45 & 2 & 3 & 0 & 0 & 0 & 0 & 0 & 0 \\
\hline \multirow[t]{3}{*}{ Barren lands } & 15 & 0 & 0 & 0 & 0 & 0 & 0 & 0 & 0 \\
\hline & 30 & 0 & 0 & 0 & 0 & 0 & 0 & 0 & 0 \\
\hline & 45 & 0 & 0 & 0 & 0 & 0 & 0 & 0 & 0 \\
\hline \multirow[t]{3}{*}{ Fallow lands } & 15 & 0 & 6 & 0 & 0 & 0 & 0 & 0 & 0 \\
\hline & 30 & 0 & 6 & 0 & 0 & 0 & 0 & 0 & 0 \\
\hline & 45 & 0 & 2 & 0 & 0 & 0 & 0 & 0 & 0 \\
\hline
\end{tabular}

Mucor spp. and F. solani were found frequently occurring almost at all the depths with a different number of spores per gram of soil. F. solani was not found in orchards as well as in barren land while isolated from all depths in fallow and vegetable fields and in the forest only found at 15 and $30 \mathrm{~cm}$.

Different isolates of Fusarium spp. were isolated from soil samples collected from a mangrove forest Malaysia were isolated using soil dilution technique. Based on identification using morphological characteristics, $F$. 
solani was the most common species recovered from soil (Zakaria et al., 2010). Mucor spp. was absent in barren and fallow lands while prevailing in other lands types. Mucor spp. was isolated in maximum number in forest, orchard and vegetable fields except for $15 \mathrm{~cm}$ depth of vegetable fields mentioned.

The presence of surface contaminants was not observed at the plough and root depths. This is primarily linked with the physical and chemical properties of the soil at root depth. It links stronger with the nature of the dead plant material and soil moisture percentage. Mucor spp., F. solani, A. niger, Penicillium spp., A. alternata, Curvularia spp., Rhizopus spp., and Helminthosporium spp. are soilborne as well as seed borne with respect to their count on feeding roots in the soil and has the potential to become problematic for forest and orchards. Mostly saprophytic fungi like Mucor and Rhizopus spp., grow on organic substances including dead plant debris or animal waste materials in soil (Kim et al., 2014). Travelling of plant pathogenic fungi below ploughing depth creates an alarming situation for deep-rooted crops infestation in future. Barren and fallow lands have lack of organic matter in these land use types (Allison, 1973). In the present studies, these land use types remained free from fungi at all depths.

Measuring microbial biomass is a valuable tool for understanding and predicting long term effects on changes in land use and associated soil conditions (Sharma et al., 2004).

\section{REFERENCES}

Akhtar, K. P., M. Y. Saleem, M. Asghar and M. A. Haq. 2004. New report of Alternaria alternata causing leaf blight of tomato in Pakistan. Plant Pathology, 53: 816-816.

Alcorn, J. L. 1988. The taxonomy of" Helminthosporium" species. Annual Review of Phytopathology, 26: $37-$ 56.

Allison, F. E. 1973. Soil organic matter and its role in crop production. Elsevier, New York, USA.

Altieri, C., D. Cardillo, A. Bevilacqua and M. Sinigaglia. 2007. Inhibition of Aspergillus spp. and Penicillium spp. by fatty acids and their monoglycerides. Journal of Food Protection, 70: 1206-1212.

Ashwathi, S., C. Ushamalini, S. Parthasarathy and S. Nakkeeran. 2017. Morphological and molecular characterization of Fusarium spp. associated with Vascular Wilt of Coriander in India. Journal of Pharmacognosy and Phytochemistry, 6: 1055-
1059.

Azam, F., S. Farooq and A. Lodhi. 2003. Microbial biomass in agricultural soils-determination, synthesis, dynamics and role in plant nutrition. Pakistan Journal of Biological Sciences, 6: 629639.

Barnett, H. L. and B. B. Hunter. 2003. Illustrated Genera of Imperfect Fungi. APS Press, St. Paul, MN, USA.

Coombe, R. G., J. J. Jacobs and T. R. Watson. 1968. Constituents of some Curvularia species. Australian Journal of Chemistry, 21: 783-788.

Corison, C. A., C. S. Ough, H. W. Berg and K. E. Nelson. 1979. Must acetic acid and ethyl acetate as mold and rot indicators in grapes. American Journal of Enology and Viticulture, 30: 130-134.

DeLorenzo, M. E., G. I. Scott and P. E. Ross. 2001. Toxicity of pesticides to aquatic microorganisms: a review. Environmental Toxicology and Chemistry, 20: 8498.

Duarte, G. F., A. S. Rosado, L. Seldin, A. C. Keijzer-Wolters and J. D. van Elsas. 1998. Extraction of ribosomal RNA and genomic DNA from soil for studying the diversity of the indigenous bacterial community. Journal of Microbiological Methods, 32: 21-29.

Filion Cassel, D. K. and A. G. Wollum. 1999. Effects of soil samplesize and included root and wood on bulkdensity in forested soils. Soil Science Society of America Journal, 45: 135-138.

Ghuffar, S., G. Irshad, F. Naz, H. Rosli, S. Hyder, N. Mehmood, M. A. Zeshan, M. M. Raza, C. G. Mayers and M. L. Gleason. 2017. First report of two Penicillium spp. causing post harvest fruit rot of grapes in Pakistan. Plant Disease.

GOP. 2016. Government of the Punjab, Agriculture Department. Punjab Information Technology Board, Lahore, Pakistan.

Haney, R., A. Franzluebbers, F. Hons, L. Hossner and D. Zuberer. 2001. Molar concentration of K2SO4 and soil $\mathrm{pH}$ affect estimation of extractable $\mathrm{C}$ with chloroform fumigation-extraction. Soil Biology and Biochemistry, 33: 1501-1507.

Hütsch, B. W. 2001. Methane oxidation in non-flooded soils as affected by crop production. European Journal of Agronomy, 14: 237-260.

Kim, J. Y. and S. Y. Baek. 2011. Molecular and morphological identification of fungal species isolated from bealmijang meju. Journal of Microbiology and Biotechnology, 21: 1270-1279. 
Kim, M. J., P.-W. Park, J.-Y. Ahn, K.-H. Kim, J. Y. Seo, J.-H. Jeong, M.-J. Park, J.-W. Jung and Y.-H. Seo. 2014. Fatal pulmonary mucormycosis caused by Rhizopus microsporus in a patient with diabetes. Annals of Laboratory Medicine, 34: 76-79.

Konig, H. and F. Jurgen. 2009. Biology of Microorganisms on Grapes, in Must and in Wine. Springer, Verlag Berlin Heidelberg, Germany.

Larone, D. H. 1995. Medically Important Fungi - A Guide to Identification 3rd ed., ASM Press, Washington, DC, USA.

Nandhini, B. and R. M. Josephine. 2013. A study on bacterial and fungal diversity in potted soil. International Journal of Current Microbiology and Applied Sciences, 2: 1-5.

O'donnell, A. G., M. Seasman, A. Macrae, I. Waite and J. T. Davies. 2001. Plants and fertilisers as drivers of change in microbial community structure and function in soils. Plant and Soil, 232: 135-145.

Parr, J., R. Papendick, S. Hornick and R. Meyer. 1992. Soil quality: attributes and relationship to alternative and sustainable agriculture. American Journal of Alternative Agriculture, 7: 5-11.

Pawar, N. V., V. B. Patil, S. S. Kamble and G. B. Dixit. 2008. First Report of Aspergillus niger as a Plant Pathogen on Zingiber officinale from India. Plant Disease, 92: 1368-1368.
Picco, A. M. and M. Rodolfi. 2004. Assessments of indoor fungi in selected wineries of Oltrepo Pavese (Northern Italy) and Sottoceneri (Switzerland). American Journal of Enology and Viticulture, 55: 355-362.

Saito, S., T. J. Michailides and C. L. Xiao. 2016. Mucor Rot-An Emerging Postharvest Disease of Mandarin Fruit Caused by Mucor piriformis and other Mucor spp. in California. Plant Disease, 100: 1054-1063.

Sharma, P., S. C. Rai, R. Sharma and E. Sharma. 2004. Effects of land-use change on soil microbial C, N and $\mathrm{P}$ in a Himalayan watershed. Pedobiologia, 48: 83-92.

Torelli, E., G. Firrao, R. Locci and E. Gobbi. 2006. Ochratoxin A-producing strains of Penicillium spp. isolated from grapes used for the production of "passito" wines. International Journal of Food Microbiology, 106: 307-312.

Wall, A. and A. S. Virgina. 1999. Quantitative and qualitative microscale distribution of bacteria in soil. Research in Microbiology, 152: 707-716.

Zakaria, L., M. K. Foong, H. M. Hsuan, M. Zakaria and B. Salleh. 2010. Fusarium species isolated from mangrove soil in kampung pantai acheh, balik pulau, pulau pinang, malaysia. Tropical Life Sciences Research, 21: 21. 